\title{
Accounting
}

\section{Determinants of the choice of a big four auditor in the Vietnamese Stock Market}

\author{
My Tran Ngoa, Thi Bach Yen Tran ${ }^{\text {** }}$ and Kim Loi Hoc
}

\author{
${ }^{a}$ Deputy Head of Business Administration Department College of Economics, Can Tho University, Vietnam \\ ${ }^{b}$ Master of International Businees, Monash University, Australia \\ cSchool of Economics - Administration, Can Tho College, Vietnam

\begin{tabular}{l}
\hline C H R O N I C L E \\
\hline Article history: \\
Received May 152020 \\
Received in revised format May \\
162020 \\
Accepted June 292020 \\
Available online \\
June 292020 \\
\hline Keywords: \\
Big Four auditor \\
Determinants \\
Capital structure \\
Concentrated ownership \\
Decision making
\end{tabular}

The study was conducted to examine the determinants on the choice of a Big Four auditor of listed firms in the Vietnamese stock market. Data were hand-collected from 511 non-financial firms in the period 2015 - 2017. The research results show that ownership concentration and foreign ownership had a positive significant impact on the choice of a high-quality Big Four auditor. Meanwhile, board size was negatively associated with the selection of large auditing firms. However, there was no statistical evidence on the effect of the proportion of independent directors and CEO duality on the likelihood of choosing a Big Four auditor.

\section{Introduction}

In the early 1990s, in order to develop and integrate with the world economy, independent audit activities in Vietnam were reestablished with the establishment of the Vietnam Auditing Company (VACO) in May 1991. After that, many other Vietnamese auditing firms were founded along with the presence of international and joint venture auditing firms. Currently, the independent audit market consists of several leading auditing firms in the world such as the Big Four, including Deloitte Touche Tohmatsu Limited (Deloitte), Klynveld Peat Marwick Geordeler (KPMG), Ernst and Young (E\&Y), and PricewaterhouseCoopers (PwC). These foreign auditing firms have the largest team of professional staff, and actively participate in training and developing professional associations in Vietnam. These associations are the key actors involved in the process of finalizing the legal framework on the management of accounting and auditing activities in Vietnam. Upon close cooperation with the Ministry of Finance, the State Audit Office, and the State Security Commission, the Vietnam Association of Certified Public Accountants (VACPA) has introduced and put a number of International Auditing Standards (ISA), International Accounting Standards (IAS), and International Financial Reporting Standards (IFRS) into practice, bringing Vietnam's accounting and auditing system closer to the global standards.

* Corresponding author

E-mail address: ttbyen@ctu.edu.vn (T. B. Y. Tran) 
Along with the development of independent audit, the Vietnamese stock market, after going through more than 17 years of construction and development, has also made certain progress. Particularly, it has become an important capital mobilization channel in the market economy and increasingly asserted an important role in promoting the socio-economic development of the country. However, in comparison with the global and regional markets, Vietnam's stock market is still in the emerging stage. There are many aspects that need to be further improved and developed in the direction of openness, fairness, and transparency in consistence with international practices and standards. Therefore, the issue of improving information transparency in audited financial statements is given more attention. As a result, the audited financial statements of public companies and securities trading organizations in the Vietnamese stock market plays an important role with multiple different objects and the investor community. In addition, auditing is an indispensable activity in the corporate governance control system, allowing stakeholders to obtain honest and objective financial and accounting information. More and more companies are selecting high-qualified auditing firms to audit their financial statements. An enterprise has to pay a certain amount of money to acquire the auditing services from respective quality auditing firms (Datar, Feltham, \& Hughes, 1991). There has been a significant amount of research on the selection of auditing firms worldwide, mainly focusing on markets such as the U.S., Australia, and the U.K. As for emerging markets, researches on this field is rather limited, except for a few studies in the context of Chinese, Malaysian, Taiwanese and Indonesian markets (Chi \& Weng, 2014; Darmadi, 2011; Lin \& Liu, 2009; Nasrudin, Mohamed, \& Shafie, 2017). Particularly for the Vietnamese market, there has been almost no scientific research on the factors affecting the selection of auditing firms by listed companies. Liu and Lu (2007) suggested that the corporate governance control system has a positive impact on corporate financial statements and auditing processes. Specifically, a corporate governance system will affect whether the company selects quality auditing companies to audit its financial statements. Thus, in order to ensure the reliability of the financial statements, not only do enterprises have to decide to select a qualified independent auditor, but they must also comply with their governance mechanisms, as well as ensure its members' and stakeholders' interests. Because of the aforementioned issues, it is very essential to conduct research on "Determinants on the choice of Big Four auditor in the Vietnamese stock market".

\section{Literature review}

Both authorities and public investors pay great attention to the essential role of corporate governance in improving financial statements and auditing processes (Ashbaugh \& Warfield, 2003). In general, the independent auditor can be considered as a tool of corporate governance. Independent auditor plays a crucial role in verifying the reliability of accounting information in the financial statements provided to shareholders or investors (Abdel-Khalik, 2002). A number of previous studies have concluded that companies tend to choose a high-quality auditor to enhance their governance control system and reduce potential risks (Fan \& Wong, 2005). In other words, a low-quality auditor may not be able to effectively control the financial reporting process of their customers (Fan \& Wong, 2002). Therefore, the quality of the independent audit will directly affect the corporate governance control system (Cohen, Krishnamoorthy, \& Wright, 2002). With respect to a manager, there has been a compromise between hiring a high-quality auditor to improve the corporate governance control system and hiring a low-quality auditor to maintain private benefits that could be extracted from a weak governance control mechanism. For that reason, the choice of the independent auditor is an important consideration with reference to both theoretical and practical perspectives (Fan \& Wong, 2002). Normally, audit firms with high competence and low moral hazards are believed to be the ones possessing strong financial resources, large human resources and long-standing brands. Empirical studies have shown that the need for independent auditors as a corporate governance mechanism for companies in the United Kingdom and the United States can be considered as a quality assurance provided by auditing companies. Cohen et al. (2002) suggested that stakeholders require financial information to be truly reliable, so external audit plays a role in corporate governance as an important monitoring tool in the financial reporting process. In other words, independent audit is a crucial component of corporate governance control (DeFond, Wong, \& Li, 1999). Cohen et al. (2002) found a positive relationship between the quality of corporate governance control and the reliability of financial reports. Large audit firms with high-quality auditors will be more independent and high-qualified since they are more likely to detect and report false or abnormal information in financial statements, thus effectively monitoring and alleviating corporate problems (Ashbaugh \& Warfield, 2003; DeFond, 1992). In recent years, the audit function has grown and played a more active role in corporate governance mechanism in developed economies (Cohen et al., 2002; Fan \& Wong, 2005). However, corporate governance control also has a positive impact on the quality and effectiveness of external audits (Abbott et al., 2007; Ashbaugh \& Warfield, 2003). The corporate governance control mechanisms have to ensure that the firms appoint qualified auditors who can conduct independent and effective monitoring during the company's financial reporting process as well as certify that the financial statements are presented in accordance with the General Accepted Accounting Principles (GAAP). Therefore, corporate governance plays an essential role in improving the reliability and usefulness of financial statements for all stakeholders (Fan and Wong, 2005). On the other hand, without corporate governance control, it is difficult to prevent company managers from infringing upon the interests of the company and other stakeholders if the auditor could not be able to detect and maintain its role effectively (Marnet, 2005). Certainly, the association between corporate governance control and independent audit (including selecting an auditor and switching from one auditor to another) is an important issue that needs to be studied in-depth. Based on the theoretical foundation and relevant studies, a number of research hypotheses have been formulated about the effect of 
characteristics of corporate governance on the choice of high-quality auditors, represented by Big Four - a group of four international auditing firms. Proposed factors include the concentration of ownership, proportion of independent board directors, CEO duality, board size and foreign ownership.

\subsection{The concentration of ownership}

Depending on the ownership equity, shareholders have different levels of influence on decision making within the company. According to Vietnamese regulations, listed companies must publish major shareholders of the company periodically (i.e. those who own more than $5 \%$ of the total voting rights 1 ). In addition, they are obliged to report quarterly and annually as well as disclose information on shareholder movements to the State Security Commission and Stock Exchange in accordance with the regulations of the State Security Commission. ${ }^{2}$ Many public companies have a number of majority shareholders with controlling rights. While the presence of these shareholders can help to monitor the company's board of management more closely, the weaknesses in the legal and regulatory framework can lead to the misuse of other shareholders among majority shareholders in the company. Hence, ownership structure affects corporate governance control and corporate value in complex ways. A controlling shareholder with a high level of ownership has a higher chance of extracting the company's resources at the expense of minority shareholders. There could be existed a potential information asymmetry among majority and minority shareholders and thus reducing the quality of their financial statements (Cohen et al., 2002). Chau and Leung (2006) also suggest that ownership concentration is negatively related to an effective internal corporate governance mechanism. Problems in the financial reporting process may exist which allows controlling shareholders to accumulate personal interests in highly concentrated companies (Fan \& Wong, 2002). Therefore, in order to reduce the level of supervision of auditing firms in controlling shareholders' personal interest maximization, they may choose a low-quality audit firm (Lin \& Liu, 2009). In contrast, controlling shareholders believe that the enterprise needs to convince minority shareholders and potential investors of the reliability of its corporate governance mechanism and financial reports, thus ensuring that their benefits are well protected. This concern may lead to the appointment of a high-quality auditor to review the company's financial statements (Darmadi, 2011; Fan \& Wong, 2005; Reed et al., 2004). Evidence of the relationship between ownership concentration and the selection of the audit firm is provided by previous empirical studies. The degree of ownership concentration is found to have a negative effect on the probability of hiring major audit firms in the U.S., France and thirteen Western European countries (Copley \& Douthett Jr, 2002; El Ghoul, Guedhami, Lennox, \& Pittman, 2007; Francis, Richard, \& Vanstraelen, 2009). Out of the small number of studies relating to developing countries, Lin and Liu (2009) investigated the relationship between corporate governance mechanisms and the choice of audit firms in Chinese IPO companies. The results showed that firms with high ownership concentration are less likely to appoint Big 10's auditors. However, J. P. H. Fan and Wong (2005) showed that companies with serious agency problems due to high ownership concentration are more likely to hire auditors from the Big Five using a large sample of companies from eight developing markets in East Asia. Thus, they supported the view that large audit firms can enhance investors' confidence in the capital market. Although the Vietnamese institutional environment is relatively new and unstable compared to other developed markets in the same region, listed companies in Vietnam pay great attention to the confidence of investors in the market. Therefore, it is expected that the company will use high-quality external auditors such as those in the Big Four when agency problems become more serious and ownership concentration is higher. The first hypothesis is proposed as follows:

$H_{1}$ : The higher a listed company's ownership concentration, the more likely it is to choose one of the Big Four auditing firms.

\subsection{The proportion of independent directors}

The independence of the board of directors' members is reflected in the quality of idea contribution and voting activities when making decisions within their authority. Independent board members contribute to the success of a company by providing innovative ideas. These members can bring value through new perspectives during board meetings, which may not exist if the meetings only include company owners and employees. It is believed that the independent member can present critical and constructive opinions to the parties without bias. The quality of a board member's contribution is not merely the independence, but it is also the courage to defend their opinions from common conceptions. Investors often require independent members to join the board of directors because their presence increases accountability and transparency. The involvement of independent board members is also a necessary step to attract external capital investment or when the company intends to list their shares on domestic or foreign markets. This is an indication of the company's commitment to external partners that it is willing to resolve potential conflicts and comply with widely accepted rules. According to the agency theory, an effective board of directors should consist of a majority of non-executive members who are believed to produce superior results because of their independence from the company's management activities (Dalton, Daily, Ellstrand, \& Johnson, 1998). Previous empirical studies have shown a positive relationship between the proportion of independent board directors and audit quality. Beasley

\footnotetext{
${ }^{1}$ Clause 1, Article 4, Part II, Circular 09/2010/TT-BTC

${ }^{2}$ Clause 2, Article 29, Regulations on Corporate Governance; Article 29, LCK, and Annex 3 and 4 of Circular 09/2010/TT-BTC
} 
and Petroni (2001) suggested that boards of directors with a higher percentage of external members will require a high-quality auditor to ensure effective management of the firm. O'sullivan (2000) provided evidence that the higher the proportion of independent directors, the greater the incentive to choose a high-quality audit service with a view to reinforcing investor confidence in the published financial statements. Therefore, the next hypothesis is set as follows:

$\mathrm{H}_{2}$ : The higher the proportion of a listed company's independent board directors, the more likely they are to choose Big Four.

\subsection{CEO duality}

In the modern corporate governance structure, the role of the chairman of the board of directors is to ensure that management activities bring the highest benefits to shareholders. The chairman is responsible for implementing the resolutions through shareholder meetings; as well as has the main role in supervising, appointing or replacing and compensating for senior managers (Fan \& Wong, 2002; La Porta, Lopez-de-Silanes, \& Shleifer, 1999). If the chairman of the board concurrently holds the position of CEO of the company, they will be much less carefree in monitoring and evaluating the performance of the company's management board. Therefore, in order for the chairman to perform an effective supervision function, separating between the positions of the chairman of the board of directors and the general director is essential for an effective internal corporate governance control mechanism (Cohen et al., 2002; La Porta et al., 1999). In addition, the key task of the board of directors is to ensure that the management board operates effectively, so it will be difficult to achieve this goal if the chairman is also the person assigned to manage the company. Another reason for separating these two positions is the limited amount of time since the CEO is often very busy with day-to-day management tasks and their responsibilities are often prioritized over that of the chairman of the board of directors. The board is an important player of a well-organized governance system, requiring a leadership spirit and commitment that only non-executive members of the board can implement. Therefore, the corporate governance rules of almost all countries encourage the separation of these two roles. Lin and Liu (2009) argued that separating the two roles would improve the management performance monitoring mechanism, thereby increasing the likelihood of choosing a larger audit firm. As a result, the next hypothesis is set as follows:

$H_{3}$ : A listed company with CEO duality is less likely to choose one of the Big Four auditing firms.

\subsection{Board size}

The size of an effective board of directors should meet the following conditions: (1) Hold effective and constructive discussions, (2) Make timely and appropriate decisions. (3) Organize effectively the work of the committees under the board of directors if they are established ${ }^{3}$. The number of board members should be decided in alignment with the requirements of the law as well as the specific needs of the company and shareholders. The number of board members in the Vietnamese firms should be within the limits specified in the Enterprise Law. A board of directors could have a minimum of 3 members and a maximum of 11 members ${ }^{4}$. According to the Sample Charter and Corporate Governance Regulations applicable to listed companies, the board of directors should have a minimum of 5 members and a maximum of 11 members ${ }^{5}$. At the same time, there should be approximately a third of the board members being independent and non-executive members ${ }^{6}$. There are some empirical studies showing that the performance of a board of directors may be affected by the number of board members. With appropriate policies and strategies, the company's business operations will be more effective and shareholders' benefits will become greater. The agency theory argues that boards with smaller sizes will perform better control functions because members are more connected, thus making it easier to make faster decisions (Jensen, 1993). Goodstein, Gautam, and Boeker (1994) suggested that a board size of 4 to 6 members could improve the firm's ability to make strategic decisions and be less likely to make mistakes. It is argued that a small board of directors tends to select a quality international auditing company to provide concrete evidence and build credibility so that shareholders and investors can believe the company's effective corporate governance control mechanism. This argument is consistent with Mustafa, Che-Ahmad, and Chandren (2018) who suggested that the number of board members should be reduced to an appropriate level to improve the board performance, and thus proving an effective governance mechanism. Therefore, the expectation of the next hypothesis is:

$H_{4}$ : The larger the board size of a listed company, the less likely it is to choose one of the Big Four auditing firms.

\subsection{Foreign ownership}

Foreign investors, from direct investments to investment funds, will be concerned about the quality of information disclosed in the host country's financial statements. Cooke (1992) argued that due to distance and language barriers, foreign shareholders face a higher risk of information asymmetry, so they will have higher requirements for reliability published financial

\footnotetext{
${ }^{3}$ Clause 1, Article 13, Regulation on Corporate Governance

${ }^{4}$ Clause 1, Article 109, Enterprise Law

${ }^{5}$ Article 24, Sample Charter, and Clause 1, Article 11, Regulation on Corporate Governance

${ }^{6}$ Clause 1, Article 11, Regulation on Corporate Governance
} 
statements. In the underdeveloped capital market, the presence of a significant percentage of foreign equity is expected to improve the reliability of published financial statements, including forecasted information. Karim, van Zijl, and Mollah (2013) have demonstrated that the level of foreign equity participation is a significant determinant of the selection of the auditor. There are at least two reasons supporting this finding. First, foreign investors are more likely to require strong oversight from the auditor of a competent audit firm which provides high-quality audit services because they invest in establishing a higher reputation than other companies. Second, foreign investors might be accustomed to the quality differences in the services of large and small companies in their home countries. Because of their affiliations with international companies, internationallylinked audit companies are more likely to be known by foreign investors and thus provide additional guarantees for foreign investors. Therefore, a positive relationship is expected between foreign equity ownership and the choice of a high-quality auditor.

\section{$H_{5}$ : The higher the proportion of foreign ownership, the more likely it is to choose one of the Big Four auditing firms.}

Based on the aforementioned hypotheses, the research model is shown in Figure 1. The research model includes the selection of international auditing firms as the dependent variable. Five independent variables consist of the concentration of ownership, proportion of independent directors, CEO duality, board size and foreign ownership. Besides, the model is included a group of three control variables, including financial leverage of the company, firm size and return on assets.

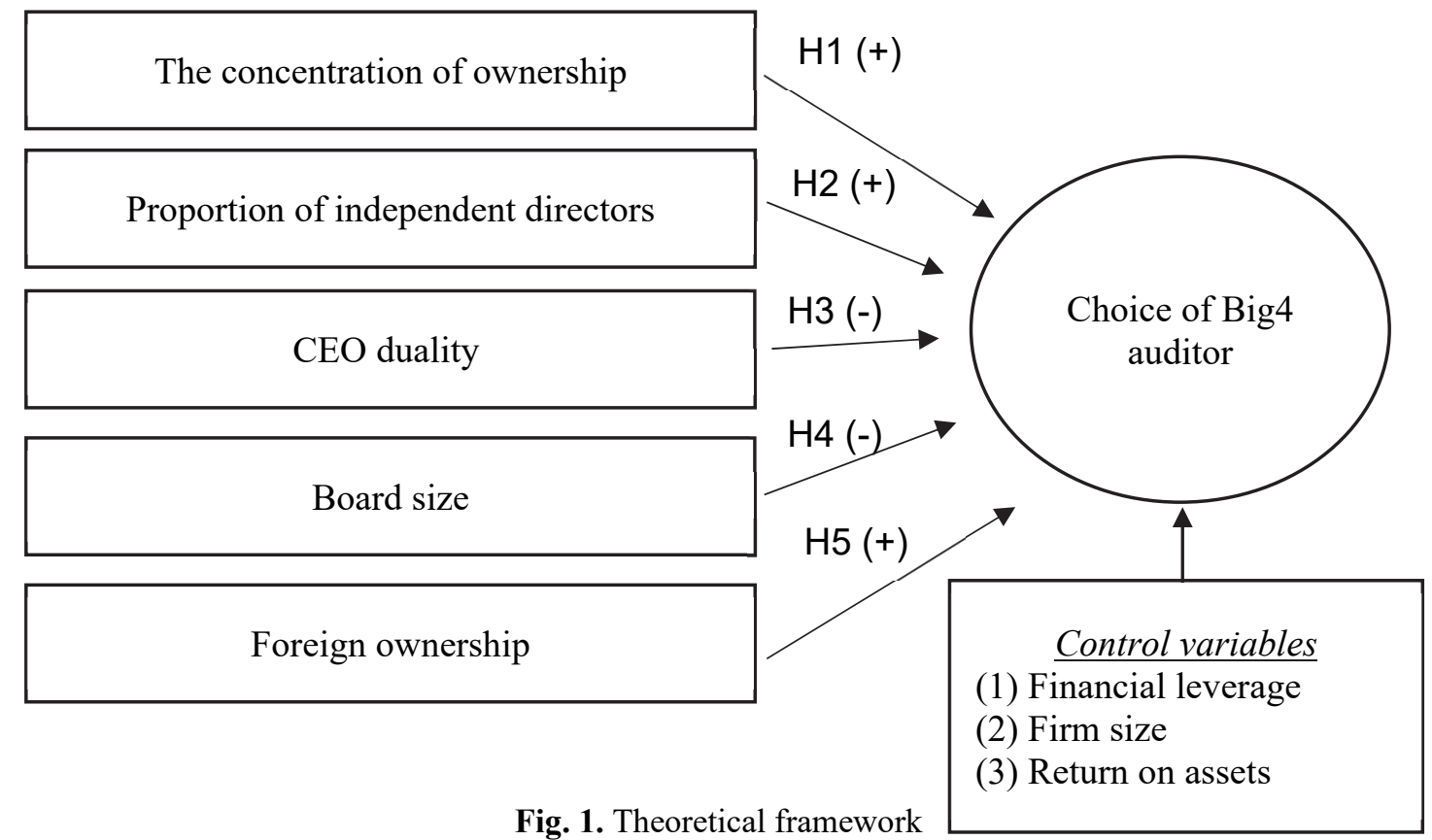

\section{Methodology}

Fig. 1. Theoretical framework

\subsection{Data collection}

The data were hand-collected from audited financial statements, annual reports, and governance reports over a three-year period between 2015 and 2017 of companies listed on the Vietnamese stock market. All collected documents are published publicly on the company's websites and electronic databases of the Vietnamese stock market. The company selected for the research sample must meet the following criteria: (i) Being a non-financial firm listed on 2 stock exchanges, Ho Chi Minh City Stock Exchange (HOSE) and Hanoi Stock Exchange (HNX). Financial companies (including companies operating in the fields of finance, banking, insurance, and real estate) will be excluded from the sample because there is a significant difference in their operating mechanism and accounting regime compared to non-financial companies; (ii) Data collected from nonfinancial companies must contain sufficient information on stock market transactions and the characteristics of the board of management (ownership structure and the board structure) are publicly available and collectable and (iii) Surveyed nonfinancial companies must have audited financial statements, annual reports, and administration reports. After filtering data based on the above sample selection criteria, the sample includes 511 companies on both stock exchanges. Research data for these variables was collected from 2015 to 2017 with a total of 1,533 observations. Of the 511 companies listed on the Vietnamese stock market in the sample, 238 companies were listed on the HOSE (accounting for 46.6\%) and 273 companies were listed on the HNX (accounting for 53.4\%). In 2015, 132 companies selected one of international auditing companies Big Four, which account for $25 \%$ of the total listed companies on the market. This percentage increases gradually over the research period. The number of listed companies which chose one of the Big Four companies in 2016 and 2017 were 138 and 
142, respectively. According to Hermalin and Weisbach (1991) and Hsiao (1985), the use of panel data has the following advantages such as (1) help to control endogenous problems; (2) control for the effect of heterogeneity; (3) provide more information on variables; (4) reduce the collinearity between independent variables; (5) increasing degrees of freedom; (6) detect and measure unobservable factors by using cross-tab and time-series data and (7) reducing random error that can occur in the analysis of the model.

\subsection{Data analysis methods}

Logit regression analysis method was used to analyze the effect of board's characteristics and company's capital structure on the selection of Big Four international auditing firms by the companies listed on the Vietnamese stock market. First, Pooled Logit regression is performed as the basic estimation method. However, the strength and effectiveness of the coefficients in panel data analysis based on this model may be inconsistent because the Pooled Logit model does not take factors that cannot be collected or have specific impacts to each enterprise into account, while the issue of individual influence is one of the most frequent phenomena in empirical studies (Baltagi, 2008). Therefore, to solve the above problem, two other estimation methods were used including Fixed Effect Model (FEM) and Random Effect Model (REM). Then, the Hausman test is used to determine whether the FEM or REM method is more appropriate. The estimation model is specified as follows:

$$
A U D C H O I C E_{i t}=\beta_{0}+\beta_{1} C_{\text {OON }}+\beta_{2} I N D_{i t}+\beta_{3} B O T H_{i t}+\beta_{4} B S I Z E_{i t}+\beta_{5} F O R E I G N_{i t}+\beta_{6} D E B T_{i t}+\beta_{7} S I Z E_{i t}+\beta_{7} R O A_{i t}+\varepsilon i t
$$

where AUDCHOICE represents for the choice of the Big Four international audit firms by companies listed on the Vietnamese stock market. This dependent variable receives a value of 1 when the firm selects an international audit firm in the Big Four, otherwise, its value will be 0 . The definitions of variables applied in the estimation model are presented in Table 1. Independent variables consist of concentration of ownership, proportion of independent directors, CEO duality, board size and foreign ownership. According to previous studies, in addition to the variables representing the characteristics of the corporate governance control system, the probability of selecting international auditing firms (Big Four) is also affected by a number of other factors, so three control variables are included in the model, namely financial leverage, firm size, and return on assets (ROA).

\section{Table 1}

Definitions of variables applied in the research model

\begin{tabular}{|c|c|c|c|}
\hline Names of variable & & Measurement & Expected sign \\
\hline Choice of Big4 auditor & AUDCHOICE & $\begin{array}{l}\text { Probability of selecting Big Four international auditing firms in the fiscal year, } \\
\text { taking a value of } 1 \text { when the firm selects an international auditing firm in the } \\
\text { Big Four, and } 0 \text { otherwise }\end{array}$ & \\
\hline Concentration of ownership & $\mathrm{CON}$ & $\begin{array}{l}\text { Percentage of the largest owner's stake in the company during the fiscal year, } \\
\text { measured by the ratio of percentage of shares owned by the largest owner in the } \\
\text { company and total number of outstanding shares. }\end{array}$ & + \\
\hline $\begin{array}{l}\text { Proportion of independent } \\
\text { directors }\end{array}$ & IND & $\begin{array}{l}\text { Proportion of independent directors in the fiscal year, measured by the ratio of } \\
\text { number of independent members in the board of directors and total number of } \\
\text { board members. }\end{array}$ & + \\
\hline CEO duality & BOTH & $\begin{array}{l}\text { Concurrent rights, taking value of } 1 \text { when the chairman of the board of directors } \\
\text { concurrently holds a position of CEO of the company, and } 0 \text { otherwise }\end{array}$ & - \\
\hline Board size & BSIZE & $\begin{array}{l}\text { Size of the board of directors in the fiscal year, measured by the number of } \\
\text { members of the company's board of directors. }\end{array}$ & - \\
\hline Foreign ownership & FOREIGN & $\begin{array}{l}\text { Percentage of shareholding of foreign investors in the fiscal year, measured by } \\
\text { the equity ratio of foreign investors and total outstanding shares of the company. }\end{array}$ & + \\
\hline Financial leverage & DEBT & Company's debt ratio in the fiscal year, measured by total debts over total assets. & \\
\hline Firm size & SIZE & $\begin{array}{l}\text { Size of the firm in the fiscal year, measured by the natural logarithm of the } \\
\text { company's total asset. }\end{array}$ & + \\
\hline ROA & ROA & $\begin{array}{l}\text { Company's return on assets at the end of the fiscal year, measured by the ratio } \\
\text { of after-tax income and total assets }\end{array}$ & + \\
\hline
\end{tabular}

\section{Results}

\subsection{Descriptive statistics}

The statistical results in Table 2 show that the percentage of ownership concentration of listed companies has a mean value of $36.45 \%$. It is worth noting that the standard deviation of this variable is $20.18 \%$. This shows a rather large variation in ownership concentration among listed companies in the market. Specifically, the lowest percentage of ownership concentration is $0.58 \%$ and the highest is $96.72 \%$. The proportion of independent members has a mean value of $64.37 \%$ while the lowest value is $0 \%$ and the highest value is $100 \%$, which means that there are some companies with a complete board of independent directors. The average board size is about 5 members, with the lowest number of members in a board being 3 members and the highest being 11 members. The mean equity ratio of foreign investors is $10.49 \%$. This ratio has the lowest value of 0 , indicating that there are companies with absolutely no foreign investors, whereas the highest value is $90.10 \%$. This proves that there are foreign-invested enterprises participating in the Vietnamese stock market. 
Table 2

Descriptive statistics of quantitative variables in the research model

\begin{tabular}{|c|c|c|c|c|c|}
\hline Variables & Unit & Mean & Standard deviation & Min & $\operatorname{Max}$ \\
\hline Ownership concentration & $\%$ & 36.45 & 20.18 & 0.58 & 96.72 \\
\hline Proportion of independent directors & $\%$ & 64.37 & 17.87 & 0 & 100 \\
\hline Board size & Member & 5.46 & 1.05 & 3 & 11 \\
\hline Foreign ownership & $\%$ & 10.49 & 14.65 & 0 & 90.10 \\
\hline Financial leverage & Times & 0.50 & 0.27 & 0.01 & 5.49 \\
\hline Firm size & Times & 11.80 & 0.65 & 10.18 & 13.86 \\
\hline ROA & Times & 0.06 & 0.11 & -1.78 & 0.96 \\
\hline
\end{tabular}

Source: Data-processing results from a sample of 511 companies listed on Vietnamese stock market during 2015-2017 (2019)

With reference to the control variables, financial leverage has a mean value of 0.50 times, with the lowest and the highest being 0.01 and 5.49 respectively. The standard deviation of financial leverage is relatively low, which shows that the trend of using debt of companies listed in the Vietnamese stock market is not too large. The mean firm size was 11.80 times. The lowest value was 10.18 and the highest value was 13.86. The mean value of the return on total assets (ROA) of listed companies is $6 \%$.

\subsection{Regression results on the impact of board characteristics and capital structure on the choice of Big Four auditor}

Table 3 presents the estimated logit regression results 7 by pooled logit, FEM and REM models as well as the Hausman test's results. The Chi-square value of the Hausman test has Prob $>$ chi $2=0.0744$, which is greater than 0.05 . As a result, the REM model is more suitable for estimating the relationship between board characteristics and capital structure and the choice of international auditing firms (Big Four). Table 3 shows that there are 5 variables out of the 8 factor variables included in the model which are statistically significant at $1 \%$ and $5 \%$. The predictive rate of the model reaches a high level of $77.43 \%$ which indicates a good level of appropriateness of the estimated model. Statistically significant variables include ownership concentration, board size, foreign ownership, financial leverage and firm size. The concentration of ownership has a positive coefficient and is statistically significant at $1 \%$. This result implies that higher the percentage of the largest shareholder's equity ownership, the more likely the company is to choose a Big Four auditor. The marginal effect of this variable $(\mathrm{dY} / \mathrm{dX}=$ 0.095) in Table 4 shows that when a company has a 1\% increase in ownership concentration, the probability of choosing a Big Four international auditing firm increases by $9.5 \%$, while keeping other factors remaining unchanged. These results are consistent with the findings of previous studies such as Fan and Wong (2005), Darmadi (2011) and Chi and Weng (2014). This empirical evidence supports the first hypothesis that there is a positive relationship between the ownership concentration and the selection of an international auditing firm. This result implies that listed companies with high levels of ownership concentration are aware of the presence of conflicts between the controlling shareholders and the remaining ones. Therefore, they employ stronger control mechanisms from quality auditing firms, such as those of Big Four, to convince minority shareholders and potential investors of the effective financial reporting process and corporate governance mechanisms. This also means that high-quality auditing firms are hired by highly concentrated listed companies to minimize conflicts of interest between majority and minority shareholders. Board size is statistically significant at $5 \%$ and has a negative impact on the probability of choosing a Big Four auditor. Hence, it could be said that the larger the board of directors is, the less likely it is to choose an international Big Four auditing firm. This result is consistent with the study of Mustafa et al. (2018) and BenHassoun, Aloui, and Ben-Nasr (2018). As a result, the fourth hypothesis of the study that there is a negative relationship between board size and the choice of a Big Four auditor is also supported. A small board of directors tends to select a quality auditing company in order to build the reputation of shareholders, ensuring that investors are aware of the company's effective governance mechanism. Foreign ownership has a statistically positive coefficient which implies a positive correlation between the equity ratio of foreign investors with the probability of selecting an international auditing firm from the Big Four. Consequently, the higher the equity ratio of foreign investors, the more likely the enterprise is to choose a reputable and qualified auditing company like those belong to Big Four. The marginal effect of this variable in Table 4 is 0.124 , which indicates that if a company has a $1 \%$ increase in the equity ratio of foreign investors, the probability of choosing an international auditing firm increases by $12.4 \%$, keeping other factors remaining unchanged. This result is consistent with previous studies such as Guedhami, Pittman, and Saffar (2009) or Karim et al. (2013). Thus, the statistical evidence supports for the fifth hypothesis that the higher the proportion of foreign equity in a listed company, the more likely it is to choose one of the Big Four auditing firms.

\footnotetext{
${ }^{7}$ The correlation between variables used in the model was tested. In general, the correlation between pairs of independent variables is quite low, so the problem of multicollinearity is not a concern in the research model.

Due to the limited presentation space, detailed correlation data will be provided upon request from readers.
} 


\section{Table 3}

Estimated results of Pooled Logit, FEM and REM

\begin{tabular}{|c|c|c|c|}
\hline Independent variables & Pooled Logit & FEM & REM \\
\hline Constant & $-22.698 * * *$ & & $-104.255 * * *$ \\
\hline Ownership concentration & $0.032 * * *$ & 0.001 & $0.136 * * *$ \\
\hline Proportion of independent directors & 0.005 & 0.011 & 0.012 \\
\hline CEO duality & 0.182 & 0.976 & 0.397 \\
\hline Board size & -0.071 & $-1.144 * *$ & $-0.710 * *$ \\
\hline Foreign ownership & $0.024 * * *$ & -0.074 & $0.139 * * *$ \\
\hline Financial leverage & $-1.040 * * *$ & $-16.233 * *$ & $-7.399 * * *$ \\
\hline Firm size & $1.738 * * *$ & 8.665 & $8.244 * * *$ \\
\hline ROA & -0.688 & 15.387 & -3.576 \\
\hline Number of observations & 1,533 & 84 & 1,533 \\
\hline Pro $>=$ chi 2 & 0 & 0.207 & 0 \\
\hline Hausman test & & \multicolumn{2}{|c|}{ Prob $>$ chi $2=0.0744$} \\
\hline The probability of correct prediction & & \multicolumn{2}{|c|}{$77.43 \%$} \\
\hline
\end{tabular}

The coefficient of financial leverage is statistically significant at $1 \%$ and has a negative impact on the possibility of choosing the Big Four. This result shows that the larger the leverage of a listed company, the less likely it is to choose an international auditing firm in the Big Four. This result is consistent with Titman and Trueman (1986). The marginal impact of financial leverage on the dependent variable is minus 0.066 , meaning that when financial leverage increases by 1 unit, the probability to choose an international auditing company will decrease by $6.6 \%$. Table 3 shows that firm size is positively related to the probability of selecting an international auditing firm in the Big Four. Particularly, if the firm has an increase in assets size of $1 \%$, the probability of choosing an international auditing company increases by $7.2 \%$, provided that the remaining factors remain unchanged. This result is consistent with Niskanen, Karjalainen, and Niskanen (2011) and the initial expectation of the study on the positive impact of firm size on the selection of an international auditing firm in the Big Four. It is also consistent with the conclusion of Willenborg (1999) that large enterprises will be forced to hire or switch to higher-quality auditing firms because their business operations are often more complex than smaller-scale enterprises.

\section{Table 4}

Logit REM regression results and marginal effects $(\mathrm{dY} / \mathrm{dX})$

\begin{tabular}{lcc}
\hline Variables & Coef. \\
\hline Constant & $-104.255^{* * *}$ \\
Ownership concentration & $0.136^{* * *}$ \\
Proportion of independent directors & 0.012 \\
CEO duality & 0,397 \\
Board size & 0.095 \\
Foreign ownership & 0.015 \\
Financial leverage & 0.005 \\
Firm size & $0.139 * * *$ & -0.007 \\
ROA & 0.124 & -0.066 \\
\hline
\end{tabular}

Number of observations $=1533$ Sigma $\mathrm{u}=9.543$ Rho $=0.965$ Pro $>=$ Chi-Square $=0.000$

Source: Data-processing results from a sample of 511 companies listed on Vietnamese stock market during 2015-2017;

Note: (***) and (**) represent for statistical significance at $1 \%$ and $5 \%$, respectively.

According to the research results in Table 3, the remaining three variables, including proportion of independent directors, CEO duality and return on assets, are not statistically significant. These variables are found to have no statistical impact on the probability of selecting an international auditing firm by a listed company in the Vietnamese stock market. This evidence is consistent with some previous studies such as Makni, Kolsi, and Affes (2012), Darmadi (2011) or Niskanen et al. (2011). These authors also failed to find a statistical relationship between these variables and the selection of a high-quality audit firm.

\section{Conclusions and recommendation}

The research has investigated the influence of board characteristics and capital structure on the selection of the Big Four international auditing firm by companies listed on Vietnamese stock market. The data was hand-collected in the period 2015 - 2017 from non-financial companies listed on HOSE and HNX. The statistical results have shown that the trend of choosing a high-quality auditing company like Big Four has been increasing over the years in the Vietnamese stock market. Besides, the results of the study also demonstrate that there was a significant difference in ownership concentration among listed companies. In the Vietnamese stock market, there are companies with completely independent boards. The board size of listed firms ranges from 3 to 11 members. The equity ratio of foreign investors also illustrates a large difference as there are companies that do not involve foreign investors, but there are other companies with more than $90 \%$ of foreign-invested capital. Logit regression with the random effect model (REM) -Table 4 was used to analyze the impact of board characteristics and 
capital structure on the selection of international auditing firms (Big Four) in the Vietnamese stock market. The analysis revealed that factors related to governance control such as ownership concentration, board size and foreign ownership directly affect the selection of international auditing firms. In particular, the greater the ownership concentration and proportion of foreign investors' equity of a company, the higher the likelihood of choosing one of the four large audit firms. Meanwhile, the board size has a negative effect on the selection of large auditing firms. However, the study did not find statistical evidence on the effect of the proportion of independent members and CEO duality on the selection of international auditing firms. In addition, the research results provided evidence that financial leverage has a negative effect on the choice of Big Four while firm size is found to have a positive effect on the firm's decision to appoint a Big Four international auditor. Based on the research results, some policy implications for listed companies are proposed with a view to increasing the selection of Big Four international auditing firms, thus enhancing the quality of financial report audits.

\section{Increasing the equity ratio of foreign investors}

The study found evidence that the higher the proportion of equity capital of foreign investors, the more likely the company is to choose an international audit firm such as the Big Four. This is because foreign investors are familiar with the audit quality and the reputation of the Big Four in their home countries. Furthermore, in order to avoid language and legal barriers in the countries where they invest, they will be more demanding more reliable financial statements. Therefore, to increase the trend of choosing an international auditing company like the Big Four, listed companies should increase the equity ratio of foreign investors. For companies calling for investment from external parties, it is recommended to increase the equity ratio of foreign investors. Because when this ratio increases, under the control and requirements of these shareholders to ensure their interests, the selection of an international auditing company will be encouraged so that all financial information will be more transparent.

\section{Increasing firm size}

The study suggests that the larger the firm size, the more likely it is to choose an international auditing firm in the Big Four. Because companies often have a large total asset value, their business operations are more complex, so investors could have a special interest in the information and quality of their financial statements. Increasing the size of the company by increasing its assets also boosts the probability of choosing an international auditing firm in the Big Four. Nevertheless, consideration should be given to the strategies that are consistent with the overall business strategy of the company.

\section{Wisely choosing the appropriate number of board members}

The study has come to the conclusion that board size has a negative influence on the choice of the Big Four international auditing firms, which means that the larger the board size, the less likely it is to select a high-quality and reputable auditing firm like those in the Big Four. This stems from the fact that a board of directors with too many members makes it difficult to manage and increase conflicts among interest groups. For that reason, in order to increase the probability of selecting an international auditing company such as the Big Four, companies listed on Vietnamese stock market should decide the size of the board in accordance with the real situation of company. Board size is considered ideal when there are 5 to 7 members. In that case, the decisions of the members will be more qualified, and the consensus rate will be higher when choosing foreign auditing firms like those in the Big Four since this choice is believed to bring more benefits for the firms.

\section{References}

Abbott, L. J., Parker, S., Peters, G. F., \& Rama, D. V. (2007). Corporate governance, audit quality, and the Sarbanes-Oxley Act: Evidence from internal audit outsourcing. The Accounting Review, 82(4), 803-835.

Abdel-Khalik, A. R. (2002). Reforming corporate governance post Enron: Shareholders' Board of Trustees and the auditor. Journal of Accounting and Public Policy, 21(2), 97-103.

Ashbaugh, H., \& Warfield, T. D. (2003). Audits as a corporate governance mechanism: Evidence from the German market. Journal of International Accounting Research, 2(1), 1-21.

Baltagi, B. (2008). Econometric analysis of panel data: John Wiley \& Sons.

Beasley, M. S., \& Petroni, K. R. (2001). Board independence and audit-firm type. Auditing: A Journal of Practice \& Theory, 20(1), 97-114.

Ben-Hassoun, A., Aloui, C., \& Ben-Nasr, H. (2018). Demand for audit quality in newly privatized firms in MENA region: Role of internal corporate governance mechanisms audit. Research in International Business and Finance, 45, 334-348.

Chau, G., \& Leung, P. (2006). The impact of board composition and family ownership on audit committee formation: Evidence from Hong Kong. Journal of International Accounting, Auditing and Taxation, 15(1), 1-15.

Chi, H.-Y., \& Weng, T.-C. (2014). Managerial legal liability and Big 4 auditor choice. Journal of Business Research, 67(9), 18571869.

Cohen, J., Krishnamoorthy, G., \& Wright, A. M. (2002). Corporate governance and the audit process. Contemporary accounting research, 19(4), 573-594.

Cooke, T. E. (1992). The impact of size, stock market listing and industry type on disclosure in the annual reports of Japanese listed corporations. Accounting and business research, 22(87), 229-237. 
Copley, P. A., \& Douthett Jr, E. B. (2002). The association between auditor choice, ownership retained, and earnings disclosure by firms making initial public offerings. Contemporary Accounting Research, 19(1), 49-76.

Dalton, D. R., Daily, C. M., Ellstrand, A. E., \& Johnson, J. L. (1998). Meta-analytic reviews of board composition, leadership structure, and financial performance. Strategic management journal, 19(3), 269-290.

Darmadi, S. (2011). Board diversity and firm performance: the Indonesian evidence. Corporate ownership and control Journal, 8.

Datar, S. M., Feltham, G. A., \& Hughes, J. S. (1991). The role of audits and audit quality in valuing new issues. Journal of accounting and Economics, 14(1), 3-49.

DeFond, M. L. (1992). The association between changes in client firm agency costs and auditor switching. Auditing, 11(1), 16.

DeFond, M. L., Wong, T.-J., \& Li, S. (1999). The impact of improved auditor independence on audit market concentration in China. Journal of accounting and Economics, 28(3), 269-305.

El Ghoul, S., Guedhami, O., Lennox, C., \& Pittman, J. A. (2007). Ownership structure, agency problems, and auditor choice: evidence from Western European firms. Paper presented at the Proceedings of the Annual Conference of the Administrative Science Association of Canada.

Fan, J. P., \& Wong, T. J. (2002). Corporate ownership structure and the informativeness of accounting earnings in East Asia. Journal of accounting and Economics, 33(3), 401-425.

Fan, J. P. H., \& Wong, T. J. (2005). Do external auditors perform a corporate governance role in emerging markets? Evidence from East Asia. Journal of Accounting Research, 43, 35-72.

Francis, J. R., Richard, C., \& Vanstraelen, A. (2009). Assessing France's joint audit requirement: Are two heads better than one? Auditing: A Journal of Practice \& Theory, 28(2), 35-63.

Goodstein, J., Gautam, K., \& Boeker, W. (1994). The effects of board size and diversity on strategic change. Strategic management journal, 15(3), 241-250.

Guedhami, O., Pittman, J. A., \& Saffar, W. (2009). Auditor choice in privatized firms: Empirical evidence on the role of state and foreign owners. Journal of accounting and Economics, 48(2-3), 151-171.

Hermalin, B. E., \& Weisbach, M. S. (1991). The effects of board composition and direct incentives on firm performance. Financial management, 101-112.

Hsiao, C. (1985). Benefits and limitations of panel data. Econometric Reviews, 4(1), 121-174.

Jensen, M. C. (1993). The modern industrial revolution, exit, and the failure of internal control systems. The journal of finance, 48(3), 831-880.

Karim, A. W., van Zijl, T., \& Mollah, S. (2013). Impact of board ownership, CEO-Chair duality and foreign equity participation on auditor quality choice of IPO companies. International Journal of Accounting \& Information Management.

La Porta, R., Lopez-de-Silanes, F., \& Shleifer, A. (1999). Corporate ownership around the world. The journal of finance, 54(2), 471517.

Lin, Z. J., \& Liu, M. (2009). The impact of corporte governance on auditor choice: Evidence from China. Journal of International Accounting, Auditing and Taxation, 18(1), 44-59.

Liu, Q., \& Lu, Z. (2007). Corporate governance and earnings management in the Chinese listed companies: A tunnelling perspective. Journal of Corporate Finance, 13(5), 881-906.

Makni, I., Kolsi, M. C., \& Affes, H. (2012). The impact of corporate governance mechanisms on audit quality: Evidence from Tunisia. IUP Journal of Corporate Governance, 11(3), 48-70.

Marnet, O. (2005). Behavior and rationality in corporate governance. Journal of Economic issues, 39(3), 613-632.

Mustafa, A. S., Che-Ahmad, A., \& Chandren, S. (2018). Board diversity, audit committee characteristics and audit quality: The moderating role of control-ownership wedge. Business and Economic Horizons (BEH), 14(1232-2019-858), 587-614.

Nasrudin, W. A. W., Mohamed, N., \& Shafie, N. A. (2017). Corporate Governance \& Auditor Choice in Malaysia. Paper presented at the SHS Web of Conferences.

Niskanen, M., Karjalainen, J., \& Niskanen, J. (2011). Demand for audit quality in private firms: evidence on ownership effects. International Journal of Auditing, 15(1), 43-65.

O'sullivan, N. (2000). The impact of board composition and ownership on audit quality: evidence from large UK companies. The British Accounting Review, 32(4), 397-414.

Reed, R., Donoher, W. J., \& Barnes, S. F. (2004). Predicting misleading disclosures: the effects of control, pressure, and compensation. Journal of Managerial Issues, 322-336.

Titman, S., \& Trueman, B. (1986). Information quality and the valuation of new issues. Journal of accounting and Economics, 8(2), 159-172.

Willenborg, M. (1999). Empirical analysis of the economic demand for auditing in the initial public offerings market. Journal of Accounting Research, 37(1), 225-238.

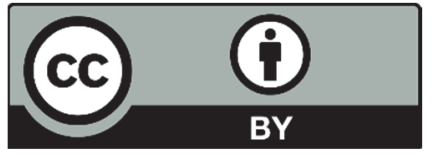

(C) 2020 by the authors; licensee Growing Science, Canada. This is an open access article distributed under the terms and conditions of the Creative Commons Attribution (CC-BY) license (http://creativecommons.org/licenses/by/4.0/). 